\title{
Adopting the Hirschman-Herfindahl Index to estimate the financial sustainability of Vietnamese public universities
}

Trung Thanh Le', Thuy Linh Nguyen², Minh Thong Trinh (10) ${ }^{3,4}$, Mai Huong Nguyen ${ }^{5}$, Minh Phuong Thi Nguyen ${ }^{1,6} \&$ Hiep-Hung Pham (10) 4,7凶

Over several decades, the Vietnamese government has increasingly cut its investment in the public higher education system and has also introduced a cost-sharing mechanism. Under this scheme, Vietnamese public universities have been seeking other sources of revenue. Despite the bold emphasis on the need for revenue diversification in higher education in Vietnam, there is little empirical evidence of the status quo of Vietnamese public higher education finance. The purpose of this paper was to fill this research gap by using the Hirschman-Herfindahl Index to estimate the degree of financial diversity in 51 public universities in Vietnam between 2015 and 2017. Our findings revealed that all institutions in this study were unsustainable due to their weak financial diversity. Suggestions for policy makers and university leaders that may enhance financial sustainability include the adoption of performance-based financial allocations and the implementation of capacity-building programs for universities with regard to fund-raising and entrepreneurship skills.

\footnotetext{
${ }^{1}$ University of Economics and Business VNU, Hanoi, Vietnam. ${ }^{2}$ Vietnam Ministry of Finance, Hanoi, Vietnam. ${ }^{3}$ University of Strathclyde, Glasgow, Scotland, UK. ${ }^{4}$ EdLab Asia Educational Research and Development Centre, Hanoi, Vietnam. ${ }^{5}$ Vietnam Ministry of Science and Technology, Hanoi, Vietnam.

${ }^{6}$ Department of Planning and Finance, VNU, Hanoi, Vietnam. ${ }^{7}$ Phu Xuan University, Hue, Vietnam. ${ }^{凶}$ email: phamhunghiep@pxu.edu.vn
} 


\section{Introduction}

revious decades have shown a steady shift in higher education finance policies across the world, from fully free higher education to cost-sharing systems (Woodhall, 1988; Heller and Rogers, 2006; Finney, 2014; Pham and Vu, 2019). University costs are now shared by a variety of stakeholders including governments, students, parents, industries, and donors. Higher education has become a quasi-market and universities are tending to behave like private firms (Marginson, 2013). Universities are now more active in seeking sources of revenue other than public funding. Thus, the degree of financial diversification reflects the health or sustainability of higher education institutions (De Dominicis et al., 2011; Garland, 2020).

Vietnam is not immune to the trend described above. Since the first cost-sharing scheme was introduced in 1997 (Vietnamese Government, 1997), the Vietnamese government has implemented a number of direct and indirect cost-sharing-linked regulations and programs, including allowing universities to levy tuition fees from students (Vietnamese Government, 2010); launching a national student loan scheme (Prime Minister, 2007); encouraging donations/philanthropy (Ministry of Education and Training, 2018) and technology transfers (Vuong, 2018; Vietnamese Government, 2018).

An emerging theme that has arisen in public discourse is the question of the financial sustainability or financial health of the Vietnamese public higher education system. For instance, talking to local media, the Minister of Education, Phung Xuan Nha, warned that Vietnamese higher education institutions that are over-dependent on tuition fees and state subsidies may face many risks (Phung, 2019). In the same vein, Bui (2019) argued that successfully accessing revenue other than public subsidies has become a crucial part of the sustainable development of higher education institutions in Vietnam.

Despite the emphasis on the need for revenue diversification in current higher education practice in Vietnam, there is little empirical evidence of the status quo of Vietnamese public higher education financing. Thus, the purpose of this paper was to fill the above research gap by using the Hirschman-Herfindahl Index (HHI) to estimate the degree of financial diversity of 51 public universities in Vietnam between 2015 and 2017. The HHI is a well-established measurement, which has been widely employed to measure the degree of diversification of financial revenue of organizations, ranging from the private sector to the public sector (Suyderhoud, 1994), the non-profit sector and higher education (Carroll and Stater, 2009; Calabrese, 2012; Mayer et al., 2014). Using the HHI, we expected to obtain a preliminary picture of the financial health or financial sustainability of public higher education in Vietnam. Our study was similar to others that also aimed to compute the degree of financial health or financial sustainability in higher education in other countries, such as England (see Garland, 2020) and other European countries (De Dominicis et al., 2011).

The paper is organized as follows. In the next section, the literature review, the need for diversifying revenue sources for public higher education institutions, from elite to massive higher education in Vietnam, governmental expenditure on higher education, and cost-sharing policies in higher education are discussed. Subsequently, a brief description of the present study, including an introduction to the HHI and data collection methods is provided. The "Results" section presents our estimations, using the $\mathrm{HHI}$ in a range of scenarios. The paper ends with a discussion and conclusions.

\section{Literature review}

The need to diversify revenue sources for public higher education institutions. Traditionally, public universities received full financial support from the government, and students undertook their higher education free of charge. However, a gradual decrease in government funding for public higher education has occurred worldwide over the past few decades (Tandberg, 2010; Joaquim and Cerdeira, 2020). This change means that cost-sharing policies or the need for public universities to seek other sources of income, such as tuition fees, donations, and knowledge transfer services, have become necessary for public universities to maintain their operations (Ayalew, 2013; Yip et al., 2020). The concept of cost-sharing has appeared in the higher education reform agendas of many countries, including European nations and the US (Clark, 1998; Etzkowitz et al., 2000) and developing/emerging countries such as Jordan (Kanaan et al., 2011). Compared to public universities in developed countries, public universities in developing/emerging countries are under higher pressure to engage in cost-sharing, partly because developing and emerging governments are facing more budget constraints than their counterparts in the developed world (World Bank, 2000).

From elite to massive higher education in Vietnam. The Vietnamese education system witnessed dramatic growth in the late 1980s, along with Doi Moi (Renovation) (Pham and Vuong, 2019). In 2018, Vietnam had 236 higher education institutions, of which 171 were public universities and 65 were private institutions (Ministry of Education and Training, 2019). In comparison, in 1987, the elite Vietnamese higher education system had only 101 public universities and no private ones. The number of enrolled students also rose dramatically from 1987 to 2018. In 2018, there were 2,162,106 university students in Vietnam (Ministry of Education and Training, 2019), a 16-fold increase over 1987, when there were only 133,000 students (Pham, 2011). With regard to the Gross Enrollment Ratio for higher education, the figure for Vietnam increased significantly, from $9.5 \%$ in 1999 to $28.5 \%$ in 2017 (UNESCO, 2020). According to Trow's (2008) classification of higher education systems, higher education in Vietnam, by the end of the 2010s, was categorized as a massive system.

According to Vuong et al., (2019), Vietnam's higher education system followed the former Soviet model in which most universities focused on teaching functions rather than research. Contrary to the former model, the current approach regards both teaching and research as indispensable functions of universities (Trinh et al., 2020). However, most universities are still teachingoriented institutions; and only a few, such as the Vietnam National University-Hanoi, the Vietnam National University-Ho Chi Minh City, and the Hanoi University of Science and Technology, claim to be research-oriented.

Governmental expenditure on higher education. With regard to higher education in particular and education in general, the Vietnamese government has increased its expenditure continuously over the past decade in terms of absolute numbers (Pham and Vuong, 2019). However, this increase has not kept pace with the ongoing massification of higher education. According to recent statistics (see Ministry of Education and Training, 2019; World Bank, 2019), the governmental expenditure per student in Vietnam as a percentage of GDP per capita ranged from $21.3 \%$ to $30.5 \%$. Due to public budget constraints, it is anticipated that the Vietnamese government will not be able to raise its current expenditure to further enhance the governmental expenditure per student as a percentage of GDP per capita.

Cost-sharing policies in higher education. From the fully subsidized financing system that applied in the early 1990s, the Vietnamese government now has a cost-sharing mechanism for 
public universities. According to Pham and $\mathrm{Vu}(2019)$, this shift may stem from the massification of higher education as mentioned above. We outline below some key cost-sharing policies in public higher education in Vietnam that have been introduced since the 1990s.

The first agenda for cost-sharing schemes. The initiation of costsharing in education has played a key role in the education policy agenda in Vietnam since the 1990s. However, Vietnamese authorities and policy-makers seldom recognize or use the term "cost-sharing" (chia sẻ chi phí in Vietnamese) in legal and official documents. Instead, "socialization" (xã hội hóa in Vietnamese) is used as a euphemistic term to refer to cost-sharing (Pham and $\mathrm{Vu}, 2019)$. The "socialization" term was first officially mentioned in the government's Resolution No. 90/CP in 1997 (Vietnamese Government, 1997). Under the "socialization" scheme, public universities in Vietnam must rely not only on financial allocation from the government but also on other sources such as tuition fees, donations and knowledge transfer. A plausible explanation of the use of the term "socialization" (xã hội hóa) rather than "cost-sharing" (chia sẻ chi phí) lies in Vietnam's socialist-oriented market economy. Thus, the Vietnamese government developed the new term "socialization" rather than adopting "cost-sharing", which originated in capitalist economies.

The tuition fee scheme for public higher education. Over the past 30 years, following the scheme of "socialization", higher education in Vietnam has transitioned from a fully free system to a cost-sharing one in which student fees have become a significant source of university income. By the academic year of 1998-1999, a public university student was required to pay a monthly tuition fee ranging from VND 50,000 to VND 180,000 (US\$ 3.60 to US\$ 12.95 in 1998), depending on his/her major. Since then, the tuition cap regulated by the government has increased gradually year by year. By the academic year of 2019-2020, the tuition fee at public universities in Vietnam ranged from VND 1,850,000 to VND 4,500,000 (US\$ 80.43 to US\$ 195.65 in 2019) per month, depending on the student's major (Prime Minister, 2015).

The National Student Loan program. Similar to many countries across the world, such as the USA and Australia (Salmi, 2001), the Vietnamese government also introduced a loan program for students to ensure accessibility and equality for underprivileged students faced with tuition fees. Following its introduction in 2007, underprivileged students in Vietnam could access the loan program to cover their study costs (Prime Minister, 2007). By 2007 , the program allowed students to borrow up to VND 800,000 (equal to US\$ 49.91 in 2007) per month with discounted interest rates of only $6 \%$ per year (Prime Minister, 2007). The loan limit has been increased gradually since then to keep pace with the inflation rate. By 1 December 2019, the monthly loan limit was VND 2,500,000 (US\$ 107.87 in 2019). Between 2007 and 2016, total loans in the program reached over VND 56 trillion and over 3.3 million students had been granted assistance (The State Bank of Vietnam, 2016).

The social and charity funds. Charity funding is also an important source of income in Western countries, which helps to fund both higher education institutions and students (Wharton et al., 2016). In Vietnam, universities are also allowed to receive social and charity funds. Decree No. 30/2012/NĐ-CP (Vietnam Government, 2012) is regarded as the first comprehensive policy that aimed to mobilize donations from society for the higher education sector as well as other public service sectors (Pham and $\mathrm{Vu}, 2019)$. This decree includes notable features on tax deductions and student rights when receiving additional state allocations outside of self-fundraising. Although we do not have any statistics available on the Vietnamese universities' revenues stemming from Social and Charity Funds, anecdotal evidence shows that this type of revenue only contributes a very small share of the total (Pham and Vu, 2019). According to the Institute for Studies of Society Economy and Environment (2015, Vietnamese people appear to favor donating their money for religious purposes rather than educational purposes.

Transfer knowledge. Like many other governments, including Israel (World Intellectual Property Organization, 2012) and China (Fuller, 2019), the Vietnamese government also has policies focusing on transferring knowledge and technology to society and the private sector with the aim of diversifying the sources of revenue for higher education institutions. Notable policies include a waiver on corporate income tax for investment in research and development (Vietnamese National Assembly, 2013), and permission for public universities to use their properties to contribute capital to joint ventures (Vietnamese Government, 2006). However, the efficiency of the above incentive policies, so far, is limited, as a financial contribution from knowledge transfer still contributes only a modest share of the overall revenue of higher education institutions in Vietnam (Nguyen, 2017).

Self-paid students at public universities. Given the increasing constraints on public budgets, along with the continuing demands for university degrees from the young population, by the mid-2010s, the Vietnamese government officially allowed public universities to open a second track to enroll fully self-paid students, i.e., students who pay tuition fees covering the whole instruction cost (Ministry of Education and Training, 2014). Pham and Vu (2019) called this policy "Dual Fee Track System in Public Institutions", which is, to a greater or lesser extent, similar to the dual fee track system described by Johnstone (2004). To further this policy, in 2014, the Vietnamese government also allowed public universities to opt for only "second track" programs (Vietnamese Government, 2014). Under this policy, 23 selected public universities agreed to stop receiving recurring subsidies from the government and instead have all self-paid programs and are granted more autonomy in various aspects of their functioning, including academic, organizational, staffing and finance. These 23 public universities are described as "autonomous" or "finance-autonomous" higher education institutions.

\section{The present study}

\section{The Hirschman-Herfindahl Index}

The origin of the HHI and its application to estimate the financial sustainability of universities. The HHI was first introduced to measure the concentration or inequality of trade and industry (Rhoades, 1995). The index has been also used to calculate the revenue concentration, revenue diversification, and financial sustainability of organizations in different sectors (e.g., see Chikoto et al., 2016). These studies regard an organization with a high level of revenue concentration or a low level of revenue diversification as having a low level of financial sustainability. In contrast, organizations with high levels of financial sustainability tend to exhibit low levels of revenue concentration or high levels of revenue diversification.

In the field of higher education, several authors have used the $\mathrm{HHI}$ to evaluate the revenue concentration, revenue diversification, or financial sustainability of universities in different contexts, including Europe (Kasperski and Holland, 2013), the US (Webb, 2015), and Malaysia (Nik Ahmad et al., 2019). In this study, we followed these studies, using $\mathrm{HHI}$ to evaluate the financial sustainability of universities in Vietnam. 
The formula of the HHI. Initially, the HHI was used by the US Department of Justice to measure the market concentration or competition (U.S. Department of Justice, 2010). Specifically, the $\mathrm{HHI}$ is calculated as the sum of the squares of the market shares of each firm participating in a certain market.

The HHI ranges between 0 and 10,000. A market would be classified as diverse and highly competitive if its HHI is $<1500$. In contrast, a market would be categorized as highly concentrated if its $\mathrm{HHI}$ is more than 2500. Between the two ends of the spectrum, a market for which the HHI is between 1500 and 2500 is classified as moderately competitive. For instance, if five firms are participating in a market with shares of $30 \%, 20 \%, 15 \%, 17 \%$ and $18 \%$ respectively, then the HHI score is $30^{2}+20^{2}+15^{2}+17^{2}+18^{2}=2138$. Thus, the market is categorized as moderately competitive.

The HHI is also used to estimate the degree of financial diversity or financial sustainability of an organization. Instead of using market shares as in the above example, in calculating financial diversity, the shares of different income sources for a certain organization would be used (Chikoto et al., 2016; Garland, 2020). Specifically, the level of financial diversity is estimated using the following formula:

$$
\sum_{i=1}^{N}\left(r_{j} / R\right)^{2}, i=1, \ldots, n
$$

where $N$ is the number of income sources, $r$ is the income from the $i$ th source, and $R$ is the total income (revenue) from all sources. In calculating financial diversity/sustainability, some authors such as Garland (2020) standardized the final HHI score from a range of $[0-10,000]$ to $[0-1]$.

In this study, we followed this standardized approach. Table 1 represents the categorization of $\mathrm{HHI}$ in two respects; market concentration/competition and financial diversity/sustainability.

Aggregation and disaggregation forms of HHI. The differences in terms of income inflows may result in different values in the HHI (Chikoto et al., 2016). For instance, in the non-profit sector, donations may be aggregated into a single income inflow or disaggregated into two sub-inflows: individual and institutional donations. Similarly, government funding may be aggregated into a single flow or disaggregated into three sub-inflows: federal, state, and local (Kerlin, 2006).

In the context of this study, we classified the income of public universities in Vietnam into four flows: (1) State allocation for instruction; (2) Tuition and fees; (3) Research and Development; and (4) Borrowing and Donations. These four flows may be further divided into 12 sub-inflows: (1.1) State recurrent subsidies (for instruction); (1.2) Earmarked non-recurrent allocation; (1.3) Capital investment; (2.1) Tuition and fees from domestic students; (2.2) Tuition and fees from international students; (3.1) State recurrent subsidies (for research and development); (3.2) State projects; (3.3) Non-state projects; (3.4) Technology transfer and service; (4.1) State borrowing; (4.2) Non-state borrowing; and (4.3) Donation. Figure 1 represents the four flows of income of public universities in Vietnam and their 12 sub-inflows, accordingly.

Data collection. Prior studies have often been based on secondary data to compute the HHIs. For instance, Garland (2020) used the Higher Education Statistics Agency (HESA)'s database to estimate HHIs for 102 universities in England. In the same vein, using the American National Center for Charitable Statistics (NCCS), Chikoto et al. (2016) computed HHIs to explore the financial volatility and growth results of non-profit organizations.

Since Vietnam does not yet have available aggregate data, which is similar to HESA's or NCCS's, we had to collect data directly from the Vietnamese universities. Data collection started in April 2019 and finished in September 2019. We sent emails to a convenience sample of 100 public universities to ask them to assign a manager (normally, the head of the finance/accounting department or the deputy rector in charge of finance/accounting), who could provide us with data on their different sources of revenue in the most recent years (see Appendix 1). As the data collection was started in April 2019, most universities did not have available data from 2018: they only provided us with data for 2017 and 2 years earlier, i.e., 2015 and 2016.

\section{Results}

Sample profile. Five months after the survey was first delivered, we had received responses from 51 universities, which implied a rate of return of $51 \%$. Table 2 illustrates the profiles of these 51 surveyed universities.

We conducted the surveys with all universities in three regions of Vietnam. More than half of our studied universities were located in Northern Vietnam, with 27 institutions, accounting for $53 \%$ of the total. This was followed by 16 universities in Southern Vietnam or $31 \%$. This result was reasonable as most of the Vietnamese higher education institutions are located in the Red River Delta and the Southeast region (Le, 2017). The number of research-oriented universities and teaching-oriented universities was almost the same, with $26(51 \%)$ and 25 (49\%), respectively.

Shares of four income inflows and 12 income sub-inflow in 2015-2017. Appendix 1 provides the descriptive statistics for the income flows (and sub-inflows) of 51 surveyed Vietnamese universities, including means, standard deviations (SDs) and respective percentages. As evident in Appendix 1, tuition fees, especially those from domestic students, have played an increasing role, forming the majority of total income for the surveyed universities. Following tuition fees, state allocations for instruction also contributed a significant share to the overall income of the surveyed universities. Specifically, this inflow ranged from $30.02 \%(2017)$ to $35.98 \%$ (2015). A closer look at the three sub-inflows of the state allocation for instruction costs shows that the state recurrent subsidy (ranging from $22.30 \%$ to 25.32\%) was more important than the two other sub-inflows, i.e., earmarked non-recurrent allocations (ranging from $4.44 \%$ to $5.60 \%$ ) and capital investment (ranging from $2.79 \%$ to $5.06 \%$ ).

Table 1 Classification of market concentration and financial diversity according to the value of HHI.

\section{Value of $\mathrm{HH}$}

Unstandardized estimation

From 0 to 1500

From 1500 to -2500

From 2500 to 10,000

Standardized estimation
From 0 to 0.15
From 0.15 to 0.25
From 0.25 to 1.00

Source: Authors synthesized from U.S. Department of Justice (2010), Chikoto et al. (2016), and Garland (2020). 


\section{Four Flows and 12 Sub-inflows of Public Higher Education Institutions in Vietnam}

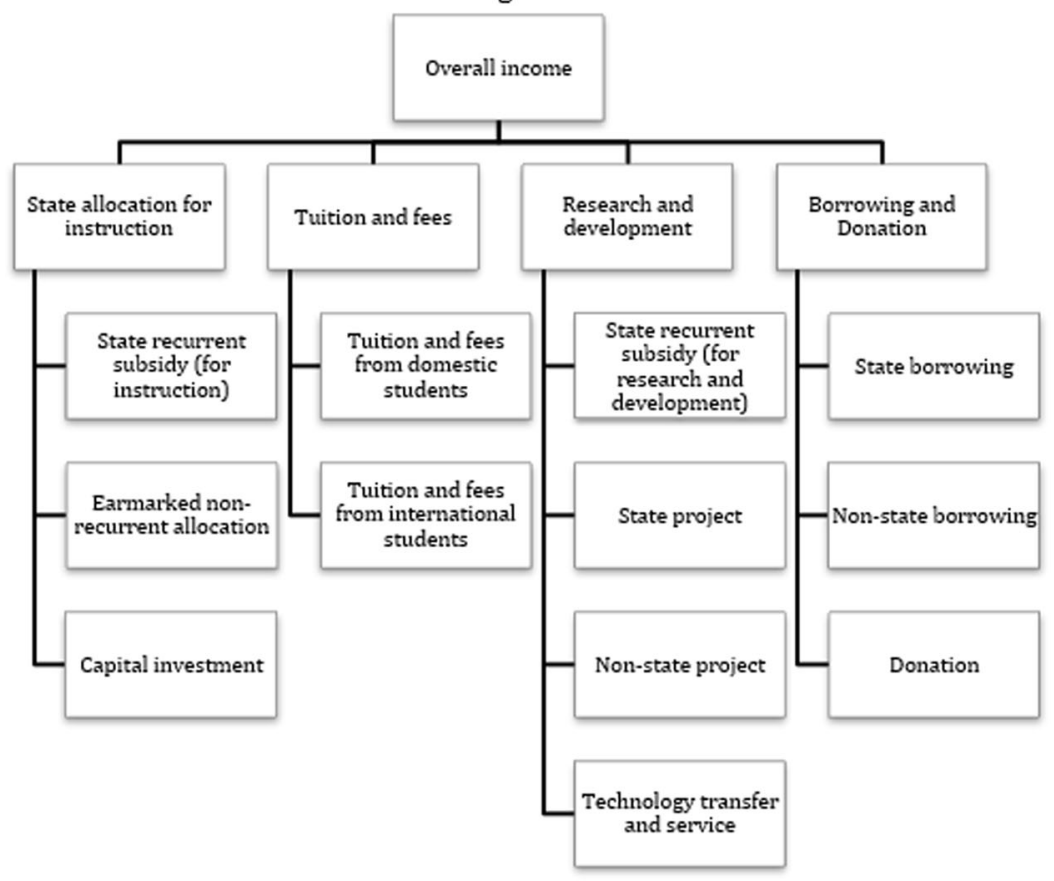

Fig. 1 Four flows and 12 sub-inflows of Public Higher Education Institutions in Vietnam.

\begin{tabular}{|llll|}
\hline \multicolumn{3}{l}{ Table 2 Descriptive profile of $\mathbf{5 1}$ surveyed universities. } \\
Feature & Mean (SD) & Frequency & \% \\
\hline $\begin{array}{l}\text { University age } \\
\text { Student size }\end{array}$ & $51.25(28.43)$ & $/$ & \\
$\quad$ Bachelor & $8423.43(9572.42)$ & $/$ & 92.55 \\
Master's & $598.44(718.2)$ & $/$ & 6.58 \\
PhD & $79.379(130.93)$ & $/$ & 0.87 \\
Location & & 27 & 53 \\
Northern Vietnam & $/$ & 24 & 47 \\
Central and Southern & $/$ & & \\
Vietnam & & 26 & \\
Type of university & $/$ & 25 & 49 \\
Research-oriented & $/$ & & \\
Teaching-oriented & &
\end{tabular}

Compared to state allocations for instruction costs and tuition and fees, the income inflows from research and development (and its four sub-inflows) and borrowing and donations (and its three sub-inflows) play relatively modest roles. Specifically, research and development only range from $7.09 \%$ to $8.8 \%$ of the total income of the 51 surveyed universities. Figure 2 shows the shares of different flows and sub-flows of incomes of 51 surveyed universities in this study between 2015 and 2017. For the details of our data, please address Appendix 2.

Estimation of HHI. Based on the data provided in Appendix 1, we estimated HHIs using two different approaches: aggregation and disaggregation. Specifically, the average HHI of 51 surveyed universities between 2015 and 2017 was $0.559(\mathrm{SD}=0.018)$ when the aggregation approach was used. The respective figure for the disaggregation approach was $0.479(\mathrm{SD}=0.022)$.

A closer look at the detailed estimation provides a comprehensive picture of the financial diversity/sustainability of different universities. Thus, Fig. 3 illustrates the distribution of average HHI scores in 51 Vietnamese universities between 2015 and 2017 according to two approaches: aggregated and disaggregated. As shown in Fig. 3, HHI was estimated with the aggregation approach and the disaggregation approach. We did not find any university with an HHI lower than 0.25. This implies that all surveyed universities in this study should be categorized as having weak financial diversity or sustainability (all HHIs $>0.25$ ). We found three universities with extremely weak financial diversity or sustainability (HHIs using aggregated or disaggregated approaches were both higher than 0.75 ).

HHIs were also estimated according to different types of universities. In this study, we categorized universities according to their age (over or under 50 years old), total enrollment (over or under 10,000 students on average between 2015 and 2017), orientation (teaching-oriented or research-oriented), and location (Northern or Central and Southern). Data on universities' ages and locations were collected from universities' websites. Data on universities' total enrollment were provided by the universities' representatives along with other data regarding their financial flows. Data on university orientation were extracted from a recent report of top Vietnamese universities in terms of research performance (Thuy Nga, 2020): those included in this list were identified as research-oriented and those outside this list were identified as teaching-oriented. Table 3 provides the HHIs in both aggregated and disaggregated approaches according to university type: over 50-year-old vs. under 50-year-old; over 10,000 students vs. under 10,000 students; teaching-oriented vs. researchoriented; and Northern vs. Central and Southern. As shown in Table 3 , in general, there are no significant differences between different types of universities with regard to $\mathrm{HHI}$, either in aggregation or disaggregation approaches (all $p$-values $>0.05$, except the $p$-value pertaining to the HHI aggregation approach between teaching-oriented and research-oriented universities).

\section{Discussion and conclusions}

In a cost-sharing context, higher education institutes across the world should seek additional sources of revenues to compensate for budget deficits. The more diverse the sources a university can obtain revenue from, the more sustainable is its financial health. 


\section{Shares of Financial Income of 51 Vietnamese universities 2015-2017: aggregation and disaggregation approaches}

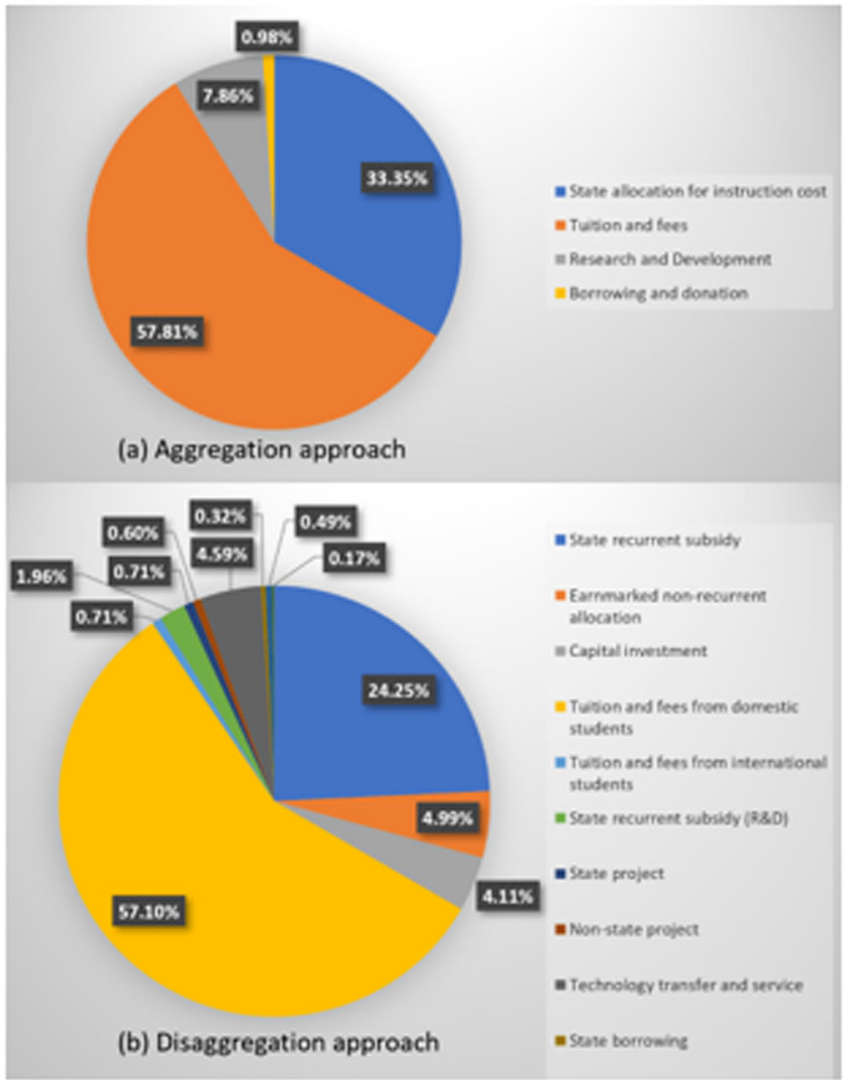

Fig. 2 Shares of financial income of 51 Vietnamese universities 2015-2017: aggregation and disaggregation approaches.

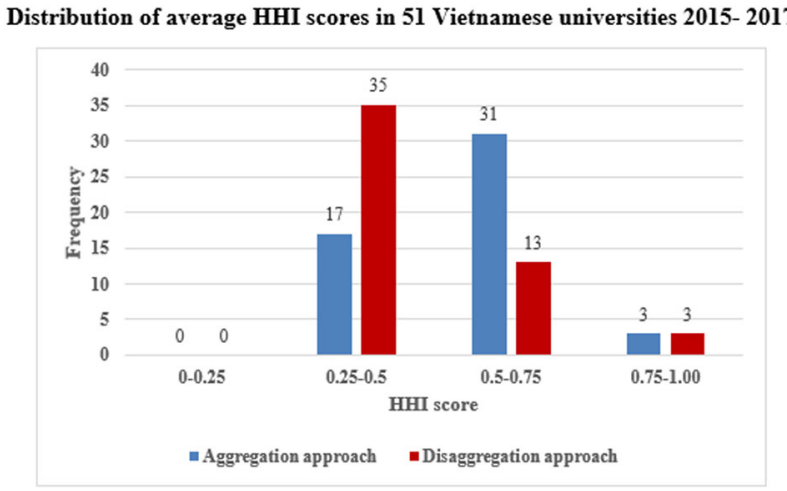

Fig. 3 Distribution of average HHI scores in 51 Vietnamese universities 2015-2017.

Vietnam is not immune to this trend. In this study, we followed some recent authors (e.g., De Dominicis et al., 2011; Garland, 2020; Schiller and Liefner, 2007), using the HHI as a proxy for the level of financial sustainability of 51 public universities in Vietnam between 2015 and 2017. Our computations indicated that, regardless of the approach used to compute the HHI (i.e., aggregation or disaggregation), Vietnamese universities are confronting an alarming situation in terms of financial health. Specifically, our findings indicate that all Vietnamese public universities included in this study showed weak financial diversity. On average, the value of the HHI between 2015 and 2017, in aggregation form, was 0.56 ; whereas the respective figure in disaggregation form was 0.48 . Both values are significantly higher than 0.25 , which is the cut-off point between two levels of financial diversity: weak and moderate. These findings also show that the financial sustainability of Vietnamese universities appear to much lower than in other countries. For instance, calculations involving 200 research-based European universities yielded an average HHI value of 0.3 (De Dominicis et al., 2011). A similar computation with 102 public and non-specialist universities in England yielded an average value of HHI of 0.42 (Garland, 2020)

A closer look at the detailed results may provide a plausible explanation for the current state of financial health of Vietnamese universities. Specifically, it appears that Vietnamese universities are over-relying on tuition fees from students, while the financial contribution from the government is modest and other sources (such as technology transfer and service or donations) are even more insignificant (see Appendix 1 and Fig. 2).

To understand this phenomenon, we must take into consideration the actual context of Vietnam.

First, the large share of tuition fees and the small share of governmental allocations in total university revenues may be interpreted as follows: In 2005, due to budget constraints, the Vietnamese government introduced a new financial subsidy mechanism based on historical data rather than a student enrollment quota. In parallel, due to the increasing demands of the younger generation for higher education, public universities started to open their doors to enroll more students (see Nguyen, 2020). Government subsidies to public universities have continued to increase over the years but the growth of revenue from tuition fees has outpaced them. Thus, the government subsidy share is shrinking while the share of tuition fees is growing. 
Second, the small contribution from research and development revenue is understandable as it reflects the chronically peripheral role of research in Vietnamese universities (Q. H. Vuong, 2019; Vuong et al., 2021). Traditionally, the academic sector in Vietnam followed the former Soviet model with two separated types of institutions: research institutes and teaching universities (Nguyen, 2020; Trinh et al., 2020). While the former specifically focused on research activities, the latter oversaw teaching at the postsecondary level and prepared future personnel for state organizations. Although the current legislation (Vietnamese National Assembly, 2012, 2018) has declared teaching, research, and knowledge transfer as the three missions of universities, research and development still receive less attention from universities than teaching. Vietnam still has relatively few universities that can be categorized as research-based (Nguyen, 2020).

Third, akin to research and development, borrowing and donations contribute and almost insignificant share of the total revenue of Vietnamese public universities. This may be interpreted as follows. Due to their low level of autonomy, Vietnamese universities still behave as state-dependent agencies rather than independent agencies (Nguyen et al., 2020). Thus, they are not willing to borrow for investment for further development. Even for those that do intend to borrow, they would face several challenges, since according to the current legislation, public universities in Vietnam are not the owners of their buildings. Thus, they do not have collateral for loans as do many other universities across the world, such as those in Austria, Spain or Italy (see Pruvot and Estermann, 2017).

The low contribution of donations to total revenue is reasonable since Vietnamese culture does not appear to regard education as a high priority for donations and charitable activities (Vuong et al., 2018; Pham and Vu, 2019). A recent survey by the Institute for Studies of Society, Economy and Environment (2015) revealed that among 1197 surveyed participants, only $24 \%$ answered that they donated money for educational purposes. The figures for other purposes, such as poverty relief, disaster relief, or supporting people with disabilities were $80 \%, 67 \%$, and $26 \%$, respectively.

Implications. The results of this study have several implications with the first implication is for academic perspective and the three others are for practical purposes.

First, this study confirms the usefulness of HHI as a proxy to evaluate the financial sustainability in higher education with a new sample from Vietnam. While previous endeavor mostly selected developed worlds such as the US (Webb, 2015), England (Garland, 2020), or contingent European countries (Kasperski and Holland, 2013), no prior studies, except Malaysia (Nik Ahmad et al., 2019) selected developing or emerging countries as a sample to compute $\mathrm{HHI}$ and evaluate the financial sustainability in higher education.

Second, as the financial health of all public universities is at risk, the Vietnamese government should be advised to reform its financial allocation mechanism for public higher education to enhance its effectiveness and efficiency. The current mechanism is mostly historically based, with $24.25 \%$ of the total revenue coming from state recurrent subsidy sub-inflows, and only $9.10 \%$ coming from state competitive funding (earmarked nonrecurrent allocation: $4.99 \%$ and capital investment: $4.11 \%$ ). Further adjustments that promote performance-based financial allocation and reduce ineffective and inefficient historically based mechanisms are suggested (see World Bank, 2020).

Third, given the current governmental expenditure on higher education in Vietnam is, in fact, not disproportionately low, compared to other developing countries as discussed at the outset, 
the Vietnamese government may opt for an investment strategy similar to China's (see Projects 985 and 211 at Yip et al., 2020); that is, focusing specifically on a very small number of highly qualified public universities that can meet world-class levels. For other universities, a more cost-sharing-linked mechanism may be adopted to encourage them to seek new sources of funding and ensure their financial sustainability. For instance, as shown earlier, the contribution of revenue from international students to the overall revenue of Vietnamese universities is still very limited, Vietnamese universities may regard international students as a potential source in the future. Pham et al. (2021) revealed some evidence of Vietnamese universities and colleges having gained fruits in international students in recent years. Strategies adopted by these institutes may offer learned lessons for other universities.

Fourth, given the low contribution from non-traditional sources of funding such as donations or knowledge transfer to overall income, the suggestion is that Vietnamese universities launch initiatives to enhance capacities in fund-raising, entrepreneurship skills and business mindsets for their faculty and staff (Ho et al., 2019). Previous studies indicated that proactive attitudes and capacities of faculty and staff are prerequisite conditions for higher education renovation (e.g., Q.-H. Vuong, 2019), including financial diversification through donations and knowledge transfer (Lockett and Wright, 2005; Speck, 2010).

Anecdotal evidence has shown some good practices undertaken by some Vietnamese universities (see Thanh, 2020). More radically, we suggest Vietnamese universities and higher education policymakers adopt the concept of the "business of science" into all their research activities. Specifically, Vietnamese universities must regard their "research and research-based activities and content [as] (commercial) products" such as "science communication, science journalism, data collection, data analysis and software development (Ho et al., 2019, p. 168). High profile "business of science" activities from developed countries such as state-funded research in the US and the UK (Nature Materials, 2006) or biotech startups in the US (Pisano, 2010) may provide examples for Vietnamese universities.

Last but not least, from a university perspective, diversifying its revenue is a must, which may, in turn, result in a more sustainable scenario for its finance. However, it would be unrealistic for one university to enhance all non-traditional revenues simultaneously (Jaafar et al., 2021). A wise strategy that focusing on only one or two new sources of revenues would be more feasible and appropriate.

Limitations and suggestions for future studies. This study has several limitations (Vuong, 2020). First, given the unavailability of secondary data, we had to conduct our own primary survey with Vietnamese universities. Therefore, our sample consisted of only 51 institutions, which is much smaller than other studies in other countries that also used the HHI to estimate the financial sustainability of higher education institutions (e.g. Garland, 2020; Kasperski and Holland, 2013; Webb, 2015). Further studies are suggested to enhance the validity of the research. Second, the data obtained in this study only covered public universities and ignored private universities. Private higher education has become an indispensable component of Vietnam's higher education system (Chau et al., 2020). Future studies should take private universities into consideration. Third, as the current study only provides a descriptive figure of the degrees of financial sustainability of Vietnamese universities, it would be worth extending this by investigating the antecedents and/or consequences of such degrees of sustainability, using inferential approach such as panel data (Frees, 2004) or Bayesian analysis (Vuong et al., 2020).

\section{Data availability}

Some specific datasets were included in the manuscript as Appendix. The other datasets are not publicly available as they form part of the author's on-going researchs. They are available on reasonable request.

Received: 5 February 2021; Accepted: 27 September 2021; Published online: 26 October 2021

\section{References}

Ayalew SA (2013) Financing higher education in Ethiopia: analysis of cost-sharing policy and its implementation. Higher Educ Policy 26(1):109-126. https:// doi.org/10.1057/hep.2012.21

Bui, V. H. (2019) Huy động nguôn lực tài chính cho giáo dục đại học công lập ở Việt Nam [Mobilizing financial resources for public higher education in Vietnam]. Tap Chi Tai Chinh. http://tapchitaichinh.vn/nghien-cuu-trao-doi/ huy-dong-nguon-luc-tai-chinh-cho-giao-duc-dai-hoc-cong-lap-o-viet-nam302114.html

Calabrese TD (2012) The accumulation of nonprofit profits: a dynamic analysis. Nonprofit Volunt Sect Q 41(2):300-324. https://doi.org/10.1177/ 0899764011404080

Carroll DA, Stater KJ (2009) Revenue diversification in nonprofit organizations: does it lead to financial stability? J Public Adm Res Theory 19(4):947-966. https://doi.org/10.1093/jopart/mun025

Chau Q, Nguyen CH, Nguyen T-T (2020) The emergence of private higher education in a communist state: the case of Vietnam'. Stud High Educ 1-16 https://doi.org/10.1080/03075079.2020.1817890

Chikoto GL, Ling Q, Neely DG (2016) The adoption and use of the Hirschman-Herfindahl Index in nonprofit research: does revenue diversification measurement matter? VOLUNTAS 27(3):1425-1447. https://doi.org/ $10.1007 / \mathrm{s} 11266-015-9562-6$

Clark BR (1998) Creating entrepreneurial universities: organizational pathways of transformation. Elsevier

De Dominicis L, Susana Elena P, Ana Fernández Z (2011) European University Funding and Financial Autonomy: a study on the degree of diversification of University Budget and the Share of Competitive Funding. JRC scientific and technical reports. https://rio.jrc.ec.europa.eu/sites/default/files/files_imported/ report/EW\%20horizontal/European\%20university\%20funding\%20and\% 20financial\%20autonomy_2011_EU.pdf

Etzkowitz $\mathrm{H}$ et al. (2000) The future of the university and the university of the future: evolution of ivory tower to entrepreneurial paradigm'. Res Policy 29(2):313-330. https://doi.org/10.1016/S0048-7333(99)00069-4

Finney J (2014) Why the finance model for public higher education is broken and must be fixed, Penn Wharton University of Pennsylvania-Public Policy Initiative. https://vtechworks.lib.vt.edu/bitstream/handle/10919/84053/Why FinanceModelMustbeFixed.pdf? sequence $=1$ \&isAllowed $=\mathrm{y}$

Frees EW (2004) Longitudinal and panel data. Cambridge University Press

Fuller DB (2019) Technology transfer in China, Oxford bibliographies. Oxford University Press

Garland M (2020) How vulnerable are you? Assessing the financial health of England's universities. Perspectives 24(2):43-52. https://doi.org/10.1080/ 13603108.2019.1689374

Heller DE, Rogers KR (2006) Shifting the burden: public and private financing of higher education in the United States and implications for Europe. Tert Educ Manag 12(2):91-117. https://doi.org/10.1007/s11233-006-0001-5

Ho M-T et al. (2019) The emerging business of science in Vietnam. In: Vuong Q$\mathrm{H}$, Tran $\mathrm{T}$ (eds) The Vietnamese social sciences at a fork in the road. Sciendo, pp. 163-177

Institute for Studies of Society Economy and Environment (2015) People's awareness of charitable activities and fundraising capabilities of Vietnamese non-governmental organizations. Institute for Studies of Society Economy and Environment http://isee.org.vn/wp-content/uploads/2018/11/nhan-thuccua-nguoi-dan-ve-hoat-dong-tu-thien-va-kha-nang-gay-quy-cua-cac-tochuc-phi-chinh-phu-viet-nam..pdf

Jaafar JA, Latiff ARA, Daud ZM, Osman MNH (2021) Does revenue diversification strategy affect the financial sustainability of Malaysian Public Universities? A panel data analysis, Higher Education Policy. https://doi.org/10.1057/s41307021-00247-9

Joaquim JA, Cerdeira L (2020) Financial accessibility in cost-sharing policies in Higher Education in Mozambique. Int J Res-GRANTHAALAYAH 8(9). https://doi.org/10.29121/granthaalayah.v8.i9.2020.1403

Johnstone DB (2004) The economics and politics of cost sharing in higher education: comparative perspectives. Econ Educ Rev 23(4):403-410. https:// doi.org/10.1016/j.econedurev.2003.09.004 
Kanaan TH, Al-Salamat MN, Hanania MD (2011) Political economy of costsharing in higher education: the case of Jordan. PROSPECTS 41(1):23-45. https://doi.org/10.1007/s11125-011-9179-5

Kasperski S, Holland DS (2013) Income diversification and risk for fishermen, Proc Natl Acad Sci USA 110(6), 2076-2081. https://doi.org/10.1073/pnas.1212278110 Kerlin JA (2006) U.S.-based international NGOs and federal government foreign assistance: out of alignment? In: Boris E, Steuerle E (eds) Nonprofits and government: collaboration and conflict. The Urban Institute Press, Washington, pp. 373-398

Le V (2017) 'Những con số "biết nói” về giáo dục đại học Việt Nam [The numbers "tell" about Vietnam's higher education]', Vietnamnet. https://vietnamnet.vn/ vn/giao-duc/tuyen-sinh/nhung-con-so-biet-noi-ve-giao-duc-dai-hoc-vietnam-389870.html

Lockett A, Wright M (2005) Resources, capabilities, risk capital and the creation of university spin-out companies. Res Policy 34(7):1043-1057. https://doi.org/ 10.1016/j.respol.2005.05.006

Marginson S (2013) The impossibility of capitalist markets in higher education. J Educ Policy 28(3):353-370. https://doi.org/10.1080/02680939.2012.747109

Mayer WJ et al. (2014) The impact of revenue diversification on expected revenue and volatility for nonprofit organizations. Nonprofit Volunt Sect Q 43(2):374-392. https://doi.org/10.1177/0899764012464696

Ministry of Education and Training (2014) Thông tư 23/2014 về đào tạo chương trình chất lượng cao trình độ đại học [Circular No. 23/2014 on advanced program training in university]. https://thuvienphapluat.vn/van-ban/Bomay-hanh-chinh/Thong-tu-23-2014-TT-BGDDT-Quy-dinh-dao-tao-chatluong-cao-trinh-do-dai-hoc-240505.aspx

Ministry of Education and Training (2018) Thông Tư 16/2018/TT-BGDĐT Quy Định Vể Tài Trợ Cho Các Cơ Sở Giáo Dục Thuộc Hệ Thống Giáo Dục Quốc Dân [Circular 16/2018/tt-bgdđt Prescribing sponsorship for educational institutions in the National Education System]. https://thuvienphapluat.vn/ van-ban/Giao-duc/Thong-tu-16-2018-TT-BGDDT-quy-dinh-ve-tai-tro-choco-so-giao-duc-thuoc-he-thong-giao-duc-quoc-dan-393562.aspx

Ministry of Education and Training (2019) The 5-year Review report on implementation of Party Central Committee's Resolution 29 on Comprehensive Renovation of Education in 2013-2018. Hanoi

Nature Materials (2006) The business of science. Nat Mater 5(12):921. https:// doi.org/10.1038/nmat1796

Nguyen HTL (2020) A review of University Research Development in Vietnam from 1986 to 2019. In: Phan LH, Doan BN (eds) Higher education in marketoriented socialist Vietnam. Springer International Publishing, Cham, pp. 63-86

Nguyen TH, Ly TMC, Tran MD et al. (2020) Nghiên cứu đề xuất các giải pháp đẩy mạnh quốc tế hóa giáo dục Việt Nam [Research and make the recommendations to promote internationalization of Vietnamese education system].http://chuongtrinhkhgd.moet.gov.vn/content/dauthaudautucong/Lists/ DuAn/Attachments/74/018.\%20Bao\%20cao\%20tom\%20tat\%20QTHGD\%20$\% 2013-1-2021 . p d f$

Nguyen TL (2020) Tăng cường các nguồn lực tài chính cho phát triển các trường đại học công lập ở Việt Nam [Improving financial resources for the development of public universities in Vietnam]. Vietnam National University, Hanoi, Unpublished document

Nguyen TTH et al. (2020) The adoption of international publishing within Vietnamese academia from 1986 to 2020: a review. Learned Publishing

Nguyen VP (2017) Các trường $Đ H$ : Nguôn thu từ $\mathrm{NCKH}$ và chuyển giao $\mathrm{CN}$ còn khiêm tốn [Universities: income from scientific research and technology transfer is still modest]. Giao duc Online. https://www.giaoduc.edu.vn/cactruong-dh-nguon-thu-tu-nckh-va-chuyen-giao-cn-con

Nik Ahmad NN, Siraj SA, Ismail S (2019) Revenue diversification in public higher learning institutions: an exploratory Malaysian study. J Appl Res Higher Educ 11(3):379-397. https://doi.org/10.1108/JARHE-04-2018-0057

Pham H-H (2011) VIETNAM: Young academic talent not keen to return. University World News. https://www.universityworldnews.com/post.php?story=201107222 01850123 Accessed 6 Aug 2020

Pham H-H, Vu H-M (2019) 'Financing Vietnamese higher education: from a wholly government-subsidized to a cost-sharing mechanism'. In: Nguyen N-T, Tran L-T (eds) Reforming Vietnamese higher education. education in the Asia-Pacific region: issues, concerns and prospects. Springer, Singapore, pp. 75-90

Pham MC, Vuong Q-H (2019) Vietnam's economy: ups and downs and breakthroughs [Kinh tế Việt Nam: Thăng trầm và đột phá]. Truth National Political Publishing House, Hanoi

Pham H-H, Vuong Q-H, Dong T-K-T, Nguyen T-T, Ho M-T, Vuong T-T, Nguyen M-H (2021) The southern world as a destination of international students: an analysis of 50 tertiary education institutions in Vietnam. J Contemp Eastern Asia 20(1):24-43. https://doi.org/10.17477/JCEA.2021.20.1.024

Phung XN (2019) Nguồn thu đại học không thể trông mãi vào học phí [University's revenues cannot always count on tuition fees]. https://tuoitre.vn/nguon-thudai-hoc-khong-the-trong-mai-vao-hoc-phi-20190724093811336.htm
Pisano GP (2010) The evolution of science-based business: innovating how we innovate'. Ind Corp Change 19(2):465-482. https://doi.org/10.1093/icc/ dtq013

Prime Minister (2007) Decision No. 157/2007/QD-TTg on credit loans for pupils and students [Quyết định 157/2007/QĐ-TTg về tín dụng đối với học sinh, sinh viên]. http://vanban.chinhphu.vn/portal/page/portal/chinhphu/hethongvanban?class_ id $=1 \&$ mode $=$ detail\&document $\_$id $=41275$

Prime Minister (2015) Decree no. 86/2015/ND-CP. On mechanism for collection and management of tuition fees applicable to educational institutions in the national education system and policies on tuition fee exemption and reduction and financial support from academic year 2015-2016 to 2020-2021 [Nghị định số 86/2015/NĐ-CP: Quy định về cơ chế thu, quản lý học phí đối với cơ sở giáo dục thuộc hệ thống giáo dục quốc dân và chính sách miễn, giảm học phí, hỗ trợ chi phí học tập từ năm hoc 2015-2016 đến năm học 2020-2021]. http://vanban.chinhphu.vn/portal/page/portal/chinhphu/hetho ngvanban?class_id $=1$ \&_page $=1$ \&mode $=$ detail\&document_id $=181665$

Pruvot EB, Estermann T (2017) University Autonomy in Europe III: the Scorecard 2017. European University Association. https://eua.eu/resources/publications/ 350:university-autonomyin-europe-iii-the-scorecard-2017.html

Rhoades SA (1995) Market share inequality, the HHI, and other measures of the firm-composition of a market. Rev Ind Organ 10(6):657-674. https://doi.org/ 10.1007/BF01024300

Salmi J (2001) Student loans: The World Bank experience. Int High Educ (22). https://doi.org/10.6017/ihe.2001.22.6912

Schiller D, Liefner I (2007) Higher education funding reform and university-industry links in developing countries: the case of Thailand. High Educ 54(4):543-556. https://doi.org/10.1007/s10734-006-9011-y

Speck BW (2010) The growing role of private giving in financing the modern university New Dir High Educ 2010 (149):7-16. https://doi.org/10.1002/ he.376

Suyderhoud JP (1994) State-local revenue diversification, balance, and fiscal performance. Public Financ Rev 22(2):168-194. https://doi.org/10.1177/ 109114219402200202

Tandberg DA (2010) Politics, interest groups and state funding of public higher education. Res High Educ 51(5):416-450. https://doi.org/10.1007/s11162010-9164-5.

Thanh H (2020) Raising awareness of new and innovative startups among the staff and lecturers [Nâng cao nhận thức về khởi nghiệp đổi mới sáng tạo trong đội ngũ cán bộ, giảng viên]. https://vnu.edu.vn/btdhqghn/?C1654/N22528/Nangcao-nhan-thuc-ve-khoi-nghiep-doi-moi-sang-tao-trong-doi-ngu-can-bo, giang-vien.htm

The State Bank of Vietnam (2016) More than 3.3 million turns of poor pupils and students have access to preferential credit loans [Hơn 3,3 triệu lượt học sinh, sinh viên nghèo được vay vốn tín dụng ưu đãi]. https://sbv.gov.vn/webcenter/ portal/m/menu/trangchu/ttskttsk_chitiet;jsessionid=hjjZp1SGzJxLCySqyb8 Sr9TynDJ1Gtf0PFD7d2ZyhlqnCTP0y0yg!-1636599546!-1385226589? centerWidth $=100 \% 25 \&$ dDocName $=$ SBV244664\&leftWidth $=0 \%$ $25 \&$ rightWidth $=0 \% 25 \&$ showFooter $=$ false\&showHeader $=$

Thuy Nga (2020) 30 leading research institutions in Vietnam [30 cơ sở đại họ dẫn đầu về nghiên cứu tại $\mathrm{VN}]$, Vietnamnet. https://vietnamnet.vn/vn/giao-duc/ khoa-hoc/30-truong-dh-dan-dau-ve-cac-chi-so-nghien-cuu-tai-viet-namnam-2019-605526.html

Trinh T et al. (2020) Factors impacting international-indexed publishing among Vietnamese educational researchers. Learn Publ 33(4):419-429. https:// doi.org/10.1002/leap.1323

Trow M (2008) Reflections on the transition from Elite to Mass to Universal Access: forms and phases of higher education in modern societies since WWII'. In: Forest J \& Altbach P (eds), International handbook of higher education. pp. 243-280, Springer, Dordrecht

U.S. Department of Justice (2010) Horizontal merger guidelines. U.S. Department of Justice https://www.justice.gov/atr/horizontal-merger-guidelines-08192010\#5c

UNESCO (2020) Gross enrolment ratio for tertiary education. UNESCO http:// tcg.uis.unesco.org/4-3-2-gross-enrolment-ratio-for-tertiary-education/

Vietnam Government (2012) Decree No. 30/2012/ND-CP: the organization and operation of Social Funds and Charity Funds [Nghị định 30/2010/NĐ-CP về tổ chức, hoạt động của Quỹ xã hội, Quỹ từ thiện]. Thuvienphapluat https:// thuvienphapluat.vn/van-ban/van-hoa-xa-hoi/Nghi-dinh-30-2012-ND-CP-tochuc-hoat-dong-quy-xa-hoi-tu-thien-137920.aspx

Vietnamese Government (1997) Resolution No. 90/CP/1997 on the direction and policy of socialization of educational medical an cultural activities [Nghi quyết 90/CP/1997 Về Phương hướng và chủ trương xã hội hoá các hoạt động Giáo dục,Y tế, Văn hoá]. Thuvienphapluat. https://thuvienphapluat.vn/vanban/giao-duc/Nghi-quyet-90-CP-phuong-huong-va-chu-truong-xa-hoi-hoacac-hoat-dong-giao-duc-y-te-van-hoa-40903.aspx

Vietnamese Government (2006) Decree No. 43/2006/ND-CP on providing for the right to autonomy and self-responsibility for task performance, organizational apparatus, payroll and finance of public non-business units [Nghị định 43/2006/NĐ-CP Quy định quyền tự chủ, tự chịu trách nhiệm về thực hiện 
nhiệm vụ, tổ chức bộ máy, biên chế và tài chính đối với đơn vị sự nghiệp công lập]. Vietnamese Government https://thuvienphapluat.vn/van-ban/Bo-mayhanh-chinh/Nghi-dinh-43-2006-ND-CP-quyen-tu-chu-tu-chiu-trachnhiem-thuc-hien-nhiem-vu-to-chuc-bo-may-bien-che-tai-chinh-doi-voidon-vi-su-nghiep-cong-lap-11313.aspx

Vietnamese Government (2010) Decree No. 49/2010/ND-CP on reduction and exemption of tuition fees, support for learning cost, collection and use of tuition applicable to educational institutions belonging to national education system from school year 2010-2011 to 2014-2015 [Nghi đinh 49/2010/NĐCP Quy Định Về Miễn, Giảm Học Phí, Hỗ Trợ Chi Phí Học Tập Và Cơ Chế Thu, Sử Dụng Học Phí Đối Với Cơ Sở Giáo Dục Thuộc Hệ Thống Giáo Dục Quốc Dân Từ Năm Học 2010-2011 Đến Năm Học 2014-2015]. Vietnamese Government https://vanbanphapluat.co/decree-no-49-2010-nd-cp-reductionand-exemption-of-tuition-fees

Vietnamese Government (2014) Resolution 77/NQ-CP on piloting new mechanisms of operation with public higher education institutions for the period of 2014-2017 [Nghị quyết 77/NQ-CP về thí đIểm đổ mớl cơ chế hoạt động đốI vớI các cơ sở giáo dục đạI học công lập giai đoạn 2014-2017]. Vietnamese Government https://thuvienphapluat.vn/van-ban/giao-duc/Nghi-quyet-77NQ-CP-2014-thi-diem-doi-moi-co-che-hoat-dong-co-so-giao-duc-dai-hoccong-lap-2014-2017-254531.aspx

Vietnamese Government (2018) Decree No. 76/2018/nd-cp dated May 15, 2018 providing guidelines of the Law on Technology Transfer [Nghị định 76/2018/ NĐ-CP Quy Định Chi Tiết Và Hướng Dẫn Thi Hành Một Số Điều Của Luật Chuyển Giao Công Nghệ]. Vietnamese Government https:// thuvienphapluat.vn/van-ban/cong-nghe-thong-tin/Nghi-dinh-76-2018-NDCP-huong-dan-Luat-Chuyen-giao-cong-nghe-380225.aspx

Vietnamese National Assembly (2012) Law on Higher Education [Luât Giáo dục Đại học]. Vietnamese National Assembly https://thuvienphapluat.vn/vanban/giao-duc/Luat-Giao-duc-dai-hoc-2012-142762.aspx

Vietnamese National Assembly (2013) Law on the Amendments to the Law on Enterprise Income Tax [Luật sửa đổi, bổ sung một số điều của Luật thuế thu nhập doanh nghiệp]. Vietnamese National Assembly https:// thuvienphapluat.vn/van-ban/doanh-nghiep/Luat-thue-thu-nhap-doanhnghiep-sua-doi-2013-197250.aspx

Vietnamese National Assembly (2018) Law on Amendments to the Law on Higher Education [Luật sửa đổi, bổ sung một số điều của Luật Giáo dục Đại Học]. Vietnamese National Assembly https://luatvietnam.vn/giao-duc/luat-giaoduc-dai-hoc-sua-doi-nam-2018-169346-d1.html

Vuong QH (2019) The harsh world of publishing in emerging regions and implications for editors and publishers: the case of Vietnam. Learn Publ 32(4):314-324. https://doi.org/10.1002/leap.1255

Vuong QH et al. (2019) Effects of work environment and collaboration on research productivity in Vietnamese social sciences: evidence from 2008 to $2017 \mathrm{sco}-$ pus data. Stud High Educ 44(12):2132-2147. https://doi.org/10.1080/ 03075079.2018.1479845

Vuong QH (2018) The (ir)rational consideration of the cost of science in transition economies. Nat Hum Behav 2(1):5. https://doi.org/10.1038/s41562-017-0281-4

Vuong Q-H (2019) Breaking barriers in publishing demands a proactive attitude. Nat Hum Behav 3(10):1034. https://doi.org/10.1038/s41562-019-0667-6

Vuong Q-H (2020) Reform retractions to make them more transparent. Nature 582(7811):149. https://doi.org/10.1038/d41586-020-01694-x

Vuong Q-H et al. (2018) Cultural additivity: behavioural insights from the interaction of Confucianism, Buddhism and Taoism in folktales. Palgrave Commun 4(1):143. https://doi.org/10.1057/s41599-018-0189-2

Vuong Q-H et al. (2020) Bayesian analysis for social data: a step-by-step protocol and interpretation. MethodsX 7:100924. https://doi.org/10.1016/j.mex.2020.100924.

Vuong Q-H et al. (2021) Mirror, mirror on the wall: is economics the fairest of them all? An investigation into the social sciences and humanities in Vietnam. Res Eval https://doi.org/10.1093/reseval/rvaa036

Webb J (2015) A path to sustainability: how revenue diversification helps colleges and universities survive touch economic conditions J Int Interdiscip Bus Res 2(7):69-97 https://core.ac.uk/download/pdf/214515334.pdf
Wharton R, Kail A, Curvers S (2016) How can charities work best in the school system? A discussion paper. https://www.thinknpc.org/wp-content/uploads/ 2018/07/School-Report_How-can-charities-work-best-in-the-schoolsystem_April16.pdf

Woodhall M (1988) Designing a student loan programme for a developing country: the relevance of international experience. Econ Educ Rev 7(1):153-161. https://doi.org/10.1016/0272-7757(88)90079-9

World Bank (2000) Higher education in developing countries: peril and promise. World Bank, Washington. https://documents.worldbank.org/en/publication/ documents-reports/documentdetail/345111467989458740/higher-educationin-developing-countries-peril-and-promise

World Bank (2019) GDP per capita. World Bank https://data.worldbank.org/ indicator/NY.GDP.PCAP.CD

World Bank (2020) Improving the performance of higher education in Vietnam strategic priorities and policy options (English). World Bank http:// documents1.worldbank.org/curated/en/347431588175259657/pdf/ Improving-the-Performance-of-Higher-Education-in-Vietnam-Strategic Priorities-and-Policy-Options.pdf

World Intellectual Property Organization (2012) Technology transfer in countries in transition: policy and recommendations. World Intellectual Property Organization https://www.wipo.int/publications/en/details.jsp?id=4118\& plang $=\mathrm{EN}$

Yip PSF et al. (2020) Is there gender bias in research grant success in social sciences?: Hong Kong as a case study. Humanit Soc Sci Commun 7(1):173. https://doi.org/10.1057/s41599-020-00656-y

\section{Acknowledgements}

This work is the output of the project, entitled "Some critical financial measures to develop higher education in Vietnam, period 2021-2030, vision 2035”, no. ĐTĐL.XH07/19, funded by the Ministry of Science and Technology of Vietnam. The authors sincerely thank the Ministry for this support.

\section{Competing interests}

The authors declare no competing interests.

\section{Additional information}

Supplementary information The online version contains supplementary material available at https://doi.org/10.1057/s41599-021-00927-2.

Correspondence and requests for materials should be addressed to Hiep-Hung Pham.

Reprints and permission information is available at http://www.nature.com/reprints

Publisher's note Springer Nature remains neutral with regard to jurisdictional claims in published maps and institutional affiliations.

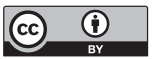

Open Access This article is licensed under a Creative Commons Attribution 4.0 International License, which permits use, sharing, adaptation, distribution and reproduction in any medium or format, as long as you give appropriate credit to the original author(s) and the source, provide a link to the Creative Commons license, and indicate if changes were made. The images or other third party material in this article are included in the article's Creative Commons license, unles indicated otherwise in a credit line to the material. If material is not included in the article's Creative Commons license and your intended use is not permitted by statutory regulation or exceeds the permitted use, you will need to obtain permission directly from the copyright holder. To view a copy of this license, visit http://creativecommons.org/ licenses/by/4.0/

(c) The Author(s) 2021 